Illinois State University

ISU ReD: Research and eData

Theses and Dissertations

$10-5-2016$

\title{
Takeover on the Tallgrass Prairie: How Lespedeza cuneata Establishes Dominance
}

Morgan Rae Walder

Illinois State University, morgan.walder@gmail.com

Follow this and additional works at: https://ir.library.illinoisstate.edu/etd

Part of the Biodiversity Commons, Biology Commons, Natural Resources and Conservation

Commons, and the Natural Resources Management and Policy Commons

\section{Recommended Citation}

Walder, Morgan Rae, "Takeover on the Tallgrass Prairie: How Lespedeza cuneata Establishes Dominance" (2016). Theses and Dissertations. 815.

https://ir.library.illinoisstate.edu/etd/815

This Thesis is brought to you for free and open access by ISU ReD: Research and eData. It has been accepted for inclusion in Theses and Dissertations by an authorized administrator of ISU ReD: Research and eData. For more information, please contact ISUReD@ilstu.edu. 


\section{TAKEOVER ON THE TALLGRASS PRAIRIE: HOW \\ LESPEDEZA CUNEATA ESTABLISHES \\ DOMINANCE}

Morgan R. Walder

31 Pages

Invasion ecology aims to study mechanisms by which invasive species are able to enter, establish, and spread within an ecosystem. This study analyzed Darwin's naturalization and the biotic resistance hypotheses as the most likely explanations for invasion by an exotic legume, Lespedeza cuneata, into a tallgrass prairie. Darwin's naturalization hypothesis posits that exotic species are less able to establish in communities that have related species, because similarity in morphology and function promotes intense competition for resources. The biotic resistance hypothesis states that competitors, herbivores, and pathogens already present in the community limit the colonization, naturalization, and persistence of invaders, therefore impeding invasion. Phenological and morphological data, photosynthetically-active radiation (PAR) measurements, Daubenmire cover, and biomass were recorded to test these hypotheses. As predicted by Darwin's naturalization hypothesis, L. cuneata mass and the mass of other legumes were negatively associated. In addition, phenological differences between $L$. cuneata and the other legumes on the study site further support Darwin's naturalization hypothesis. In order to inform conservation management, it is essential to identify mechanisms by which invasion occurs, such as was done in this study.

KEYWORDS: Invasion ecology, Invasive legume, Prairie community, Biotic resistance, Darwin's naturalization 
TAKEOVER ON THE TALLGRASS PRAIRIE: HOW

LESPEDEZA CUNEATA ESTABLISHES

DOMINANCE

MORGAN R. WALDER

A Thesis Submitted in Partial

Fulfillment of the Requirements

for the Degree of

MASTER OF SCIENCE

School of Biological Sciences

ILLINOIS STATE UNIVERSITY 
Copyright 2017 Morgan R. Walder 
TAKEOVER ON THE TALLGRASS PRAIRIE: HOW

LESPEDEZA CUNEATA ESTABLISHES DOMINANCE

MORGAN R. WALDER

COMMITTEE MEMBERS:

Victoria A. Borowicz, Chair

Joseph E. Armstrong

Diane L. Byers 


\section{ACKNOWLEDGMENTS}

I am grateful for the constant guidance and assistance of $\mathrm{V}$. Borowicz in developing and making this study a success. I would like to thank V. Borowicz and J. Armstrong for their many hours of help in the field and laboratory. Additionally, I would like to thank D. Byers for her support throughout this study, and S. Juliano for commenting on the statistics. B. Cooke, E. Dorset, T. Joray, J. Mullins, M. Rymarz, J. Sussman, K. Walder, and R. Walder assisted with field data collection and analysis, for which I am extremely thankful. A huge thank you to my family, friends, and colleagues that offered support throughout graduate school; you are all extremely appreciated and I am grateful for your kind words and helping hands. I would like to thank McLean County Parks and Recreation allowed us to utilize the John English Prairie field site. This research was partially funded by grants from Phi Sigma Biological Honors Society Beta Lambda Chapter and Illinois State University.

M.R.W. 


\section{CONTENTS}

Page

ACKNOWLEDGMENTS

$\begin{array}{ll}\text { CONTENTS } & \text { ii }\end{array}$

$\begin{array}{ll}\text { TABLES } & \text { iii }\end{array}$

FIGURES

CHAPTER I: INTRODUCTION 1

The Invasive Species Problem 1

Lespedeza cuneata, a Threat to Prairie Ecosystems 2

Hypotheses and Predictions $\quad 4$

Research Goals $\quad 5$

CHAPTER II: MATERIALS AND METHODS 26

Field Site $\quad 6$

Data Collection $\quad 6$

Statistical Analyses $\quad 8$

$\begin{array}{ll}\text { CHAPTER III: RESULTS } & 10\end{array}$

CHAPTER IV: DISCUSSION 16

Darwin's Naturalization Hypothesis 16

Biotic Resistance Hypothesis $\quad 18$

Possible Contending Hypotheses 19

Recommendations for Management $\quad 22$

CHAPTER V: RELEVANCE AND CONCLUSION 24

$\begin{array}{ll}\text { REFERENCES } & 25\end{array}$ 


\section{TABLES}

Table Page

1. Results of Principal Component Analysis 11 


\section{FIGURES}

Figure $\quad$ Page

1. Fertilizer Treatment Effects on L. cuneata Mass 11

2. Vegetative Characteristics of Collected Legumes 13

3. Flowering Times of Species on John English Prairie $\quad 14$ 


\section{CHAPTER I: INTRODUCTION}

\section{The Invasive Species Problem}

In the US, costs associated with invasion by exotic species are estimated at $\$ 120$ billion per year (Pimentel et al. 2005). While this estimate includes cost of eradication and control efforts, it does not include costs of important ecological effects (Catford et al. 2012). Ecological consequences of invasions include lost biodiversity (Eddy and Moore 1998), changes in ecosystem structure and function (Chapin et al 2000), and changes in biotic interactions such as competition with native species (Catford et al. 2012). Some invasive species can alter ecosystem function in just one growing season (McLeod et al. 2016), which shows how strong an impact these species can have after becoming established in a site. Such ecological effects can result in the loss of ecosystem services, which adds to the economic costs of invasive species removal or control (Catford et al. 2012).

Identifying mechanisms by which exotic plant invasions occur is essential for informed conservation management strategies. Because successful invasion is a product of ecosystem characteristics, species traits, and potential mechanisms (Williamson \& Fitter 1996; Daehler 2003), the manifold combinations of these factors have resulted in a large number of hypotheses. Catford et al. (2009) identified 29 leading hypotheses about plant invasion ecology. These numerous hypotheses overlap, are redundant, and typically only focus on a single mechanism (White et al. 2006). Proliferation of hypotheses limits the ability to link findings into a broader, theoretical framework that explains these mechanisms at work. Catford et al. (2009) suggest that integrating multiple hypotheses into a broader framework, instead of creating new terms and models specific to individual systems, is more useful in gaining understanding of these mechanisms. 
Invasion success is determined by three things: propagule pressure, abiotic characteristics of the area of invasion, and biotic characteristics of both the area of invasion and the invading species (Catford et al. 2009). Propagule pressure is the amount (size and number) of plant propagules that are introduced to an area and though a singular propagule could lead to the colonization of a site, continued dispersal is required for the success of the invading species. Because my focal species was established on the study site before this study began, I did not examine factors controlling dispersal. Abiotic characteristics represent constraints imposed by both geography and habitat. Biotic characteristics determine interactions within the community itself. I examined how abiotic and biotic characteristics contribute to the spread of Lespedeza cuneata, an invader in the Midwestern U.S.

\section{Lespedeza cuneata, a Threat to Prairie Ecosystems}

Lespedeza cuneata (Dum. Cours.) G. Don (Fabaceae), also known as Lespedeza juncea var. sericea, Lespedeza latissima, Lespedeza sericea, and Lespedeza serpens, is a rising threat to tallgrass prairies (USDA). Common names include silky bushclover, Chinese bushclover, and sericea lespedeza. Lespedeza cuneata is native to Asia and Australia, and is commonly found in Korea, China, Taiwan, India, and Japan (Ohiwi 1965). This aggressive, invasive legume was introduced to the southern United States in the 1800's to help control soil erosion, and provide forage (Hoveland et al. 1961). Lespedeza cuneata has now been found in many areas in the United States, and has also been introduced to South Africa, Brazil, Canada, and Mexico (Hoveland et al. 1985).

Lespedeza cuneata possesses a number of traits that enable it to meet abiotic and biotic challenges. This plant is resistant to drought due to a deep taproot, produces large numbers of 
small seed (3-5 mm), and grows readily in grasslands, pastures, along roadsides, and in many disturbed areas (Ohlenbusch et al. 2007). Plants grow from approximately one to five feet tall, and the closely-spaced stems become increasingly branched with age, forming dense thickets (USDA). Lespedeza cuneata can enter nutrient-poor sites due to its ability to fix nitrogen, and alters soil conditions through microbial communities that are established to facilitate its own growth (Coykendall and Houseman 2014, Yannarell et al. 2011). Tannins found in the leaf litter can play a large part in the soil ecosystem, and can affect germination, seedling emergence and growth, nitrogen concentration, and aboveground biomass (Langdale and Giddens 1997; Kalburtji and Mosjidis 1992).

Propagule production and dispersal have been identified as important traits enabling invasive plants to aggressively colonize new sites (Davis et al. 2000). Plants that allocate fewer resources to each seed can produce a large number of seeds, increasing the chances that some offspring will become established (Kawano 1981). These seeds are also easily transportable, which aids in easy dispersal by humans or wildlife. Lespedeza cuneata can produce up to 1,500 seeds per plant (Ohlenbusch et al. 2007).

In addition to vegetative spread through rhizomes (Woods et al. 2009), L. cuneata reproduces sexually through both out-crossing chasmogamous $(\mathrm{CH})$ flowers, and self-pollinated cleistogamous (CL) flowers (Woods 2006). This flexible reproductive strategy allows L. cuneata to successfully surmount ecological barriers that discourage reproduction. Chasmogamous flowers are insect-pollinated, primarily by bees (Cane and Snyder 1986). If pollination is poor in a season, the plant is able to produce seeds through self-pollination. Chasmogamous flowers vary from cream to white, with the top petal having pink or purple color. Since cleistogamous flowers are self-fertilized, they have closed, non-showy petals. CH and CL flowers are scattered together 
throughout the vegetative L. cuneata stem, with $\mathrm{CH}$ flowers growing in clusters from the axis of the leaf. At peak flowering time, chasmogamous flower production by L. cuneata is $>20 \mathrm{X}, 3 \mathrm{X}$ more seed per ramet, and 5X more seed per plant than that of native Lespedeza species (Woods et al. 2009). Due to the large number of flowers attracting pollinators, L. cuneata can experience greater seed set when compared to native congeners Lespedeza capitata, Lespedeza violacea, and Lespedeza virginica (Woods et al. 2009).

\section{Hypotheses and Predictions}

Based on the traits of L. cuneata and characteristics of the study site, I selected two hypotheses to test using field-collected data: Darwin's naturalization hypothesis and the biotic resistance hypothesis. Additional alternative hypotheses are discussed later in this paper.

The limiting similarity hypothesis is also known as Darwin's naturalization hypothesis and thus this name will be utilized in the following text. Darwin's naturalization hypothesis states that an exotic species is less likely to establish in communities with related species because similarity in morphology and function among taxonomically related species would promote intense competition for resources (Darwin 1859; MacArthur and Levins 1967; Callaway and Ridenour 2004; Hierro et al. 2005). This hypothesis predicts a negative correlation between abundance of exotic species and the total abundance of related species. In addition, it predicts that co-occurring species should differ in life history, morphology, and function. If this hypothesis applies to L. cuneata in a prairie community, I predict that there should be a negative correlation between the abundance of $L$. cuneata and other legumes. I further predict that $L$. cuneata should differ in life history, morphology, and function than other co-occurring legumes. 
The biotic resistance hypothesis states that competitors, herbivores, and pathogens already present in the community limit the colonization, naturalization, and persistence of newcomers, therefore impeding invasion (Levine et al. 2004; Parker and Hay 2005; Alpert 2006). This hypothesis assumes that species new to a site are not adapted to competitors in the new range and are not defended against damage from novel pathogens and herbivores. Studies of restored prairies provide support for this hypothesis (Foster et al. 2015). Restored plots, which had greater native prairie plant species and total plant cover, as well as increased species richness and diversity, showed less non-prairie species cover than plots that had not been restored. Foster et al. (2015) showed that L. cuneata cover was decreased by restoration efforts but increased in plots that had not been restored. If the saturation of the community leaves few resources available for use, as posited by the biotic resistance hypothesis, I predict that invasion by $L$. cuneata is negatively associated with the number or total cover of species found in an experimental plot.

\section{Research Goals}

This study focused on factors that allow L. cuneata to successfully spread within a community. My overarching hypothesis is that multiple life history traits allow L. cuneata to utilize nutrient-poor, sparsely vegetated sites, and suppress the growth of the native species. Through detailed observations and quantification of life-history traits and analysis of cover and aboveground biomass, I tested which of two hypotheses better explains the success of this invasive legume. Finally, I considered whether alternative hypotheses may better explain the rapid spread of L. cuneata. 


\section{CHAPTER II: MATERIALS AND METHODS}

\section{Field Site}

John English Prairie is a reconstructed prairie in Comlara Park, McLean County, IL, USA (40.621388, -89.014729). This site was agricultural land over 40 years ago. John English Prairie is located near the southern part of Evergreen Lake, which borders the prairie on the west side, and an agricultural field on the east side. This reconstructed prairie is generally burned annually in the spring, and in the year of data collection (2015) it was indeed burned in March.

To take advantage of existing background data, I conducted my observations in experimental plots originally established as part of a manipulative study on hemiparasites (Borowicz and Armstrong 2012). At the time of establishment, Pedicularis canadensis was present in each of the $96,1-\mathrm{m}^{2}$ experimental plots. One of eight treatments were randomly assigned to each plot. These were combinations of three factors: parasitic plants (no removal/removed in the spring), soil fertility (no addition/ annual addition of granular 10-10-10 N-P-K fertilizer), and shade (full sun $/ 50 \%$ shade June-October). The shade treatment was discontinued in 2010. These plots were distributed within 12 spatial blocks. Valuable background data from each plot include the years when L. cuneata was observed, biomass of native graminoids, non-legume forbs (henceforth "forbs"), L. cuneata, and other legumes harvested in 2008, biomass of L. cuneata in 2009, and the number of species present in 2009 .

\section{Data Collection}

Starting in May 2015 and continuing weekly throughout the growing season (MayOctober 2015), detailed phenological and morphological data were taken on L. cuneata and other species in the plots to determine: (1) timing of flowering, (2) height of the plant, and (3) total 
number of flowering stems. The tallest flowering individual of each species in the experimental plot was chosen for measurements for that week. Flowering times within a plot were considered to have begun when one individual of a species had begun flowering and ceased when no individual representatives of that species were in flower.

Three mature specimens per species were collected and aboveground biomass was measured in order to quantify differences in size of the legumes in our prairie community. For each species, samples were randomly selected by running a ten meter transect from a plot, used in the previous study, containing that legume species. The closest specimen to a randomlychosen number on the transect was collected and used for analysis. Legumes present on the study site included: white clover (Trifolium repens), white wild indigo (Baptisia alba), purple prairie clover (Dalea purpurea), white prairie clover (Dalea candida), round-headed bushclover (Lespedeza capitata), and silky bushclover (Lespedeza cuneata). These specimens were collected after flowering, and then dried at 60 degrees Celsius for one week and weighed to determine total aboveground dry mass.

Photosynthetically-active radiation (PAR) levels at the ground level were taken in June 2015 to compare how L. cuneata and other species attenuate the light. One measurement was taken interior on each side of the experimental plot $(50 \mathrm{~cm})$ and then the four measurements were averaged in order to get one value for each experimental plot. Measurements were taken on cloud-free days in the late morning and early afternoon between $11 \mathrm{am}-2 \mathrm{pm}$.

During the growing season in July 2015, cover (Daubenmire 1959) was determined in each plot in order to evaluate the effects of fertilizer and removal of the hemiparasitic plant $P$. canadensis on abundances of L. cuneata and functional groups of native species (grasses, nonlegume forbs, and legumes). In addition, each plot was inventoried to determine effects of 
treatments on species richness. This survey work allowed me to document the presence of rarer species.

In October 2015, all aboveground biomass was harvested in the northwest $0.25-\mathrm{m}^{2}$ corner of the $1-\mathrm{m}^{2}$ experimental plot. It was then separated into L. cuneata, graminoids, $P$. canadensis, other forbs, and remaining legumes. The biomass was then dried at 60 degrees Celsius for one week and weighed to determine the dry mass (g. $\left.0.25 \mathrm{~m}^{-2}\right)$.

\section{Statistical Analyses}

A principal component analysis (PCA) was used to examine how current community characteristics affect the aboveground biomass of $L$. cuneata in 2015. PCA was used to produce uncorrelated variables that characterized the plant community in the experimental plots. The original values for each plot were: the numbers of $\mathrm{C}_{3}$ grass species, $\mathrm{C}_{4}$ grass species, non-legume forb species, legume species other than L. cuneata, exotic species, weedy species, and the measure of photosynthetically-active radiation at ground level. The United States Department of Agriculture (USDA) was utilized to determine which species were considered weedy. Principal components with eigenvalues greater than one were retained for analysis. These scores for community characteristics were included with fertilizer treatment, spatial blocking, and hemiparasite removal as main effects in an ANCOVA to determine which factors significantly affect L. cuneata mass in the sampled portion of the plots.

In order to characterize the six legume species found on our study site, shoot length $(\mathrm{cm})$ and aboveground dry mass (g) were response variables in a MANOVA to determine differences among the species. 
The final two analyses examined how the community present several years earlier affected establishment and growth of L. cuneata. First, using only plots from which $L$. cuneata was absent in 2009, a logistic regression tested whether the number of species in the plots in 2009 (= species richness) affected subsequent establishment of L. cuneata. Then, a multiple regression was run on the entire data set (including plots with and plots without $L$. cuneata in 2009) in order to further analyze invasion by L. cuneata. For this analysis the response variable was the log-transformed L. cuneata mass in 2009 subtracted from the log-transformed mass in 2015. Thus a larger positive value indicates greater growth. Species richness and biomass of each of the functional groups from 2009 (graminoids, non-legume forbs, hemiparasite P. canadensis. and legumes other than L. cuneata) were independent variables. 


\section{CHAPTER III: RESULTS}

The principal component analysis provided a better understanding of the characteristics of the contemporary community that are associated with the success of L. cuneata. The first three principal components from analysis of the prairie community explained approximately $71 \%$ of the variance in the measurements from the plots (Table 1) and were included in the ANCOVA. The first principal component was strongly and positively associated with the number of nonlegume forb species and the number of weedy species. The second principal component was positively associated with the number of other legume species and PAR at ground level. The third principal component was positively associated with number of $\mathrm{C}_{3}$ grasses. ANCOVA indicated that factors loading strongly on principal component two were strongly and negatively associated with $L$. cuneata mass $\left(F_{1,78}=11.17, P=0.0013\right)$. Mass of $L$. cuneata decreased as available light and the abundance of legumes (excluding L. cuneata) increased (slope=-0.261, $\mathrm{se}=0.084)$. The first and third principal components, which were associated with numbers of $\mathrm{C}_{3}$ and $\mathrm{C}_{4}$ grasses, forbs, weedy species, and exotic species in the community, were not associated significantly with L. cuneata biomass $\left(P>0.05\right.$ for both). Spatial block $\left(F_{11,78}=5.33, P=\right.$ $<0.0001)$ and fertilizer $\left(F_{1,78}=6.87, P=0.0105\right.$, Fig. 1) were significant effects. Plots that received the fertilizer treatment had lower amounts of $L$. cuneata mass than plots that did not receive the fertilizer treatment, consistent with findings (Brandon et al. 2004). Absence of fertilizer resulted in a higher biomass of L. cuneata. 
Table 1. Results of principal components analysis. Factors 1 through 3 explained approximately $71 \%$ of the variance in the measurements. Forbs and weedy species load heavily onto Factor 1. Photosynthetically-active radiation (PAR) and all legumes other than Lespedeza cuneata load onto Factor 2. $\mathrm{C}_{3}$ grasses load onto Factor 3.

\begin{tabular}{lccccc}
\hline & Factor 1 & Factor 2 & Factor 3 & Factor 4 & Factor 5 \\
\hline C $_{3}$ Grasses & 0.11639 & 0.04863 & 0.95373 & -0.00631 & 0.16197 \\
C 4 Grasses & -0.06143 & 0.07459 & 0.00098 & 0.98780 & 0.09996 \\
Forbs & 0.81366 & 0.30136 & 0.30746 & -0.05825 & 0.04420 \\
Legumes (except L. cuneata) & 0.14677 & 0.78069 & -0.10863 & 0.05398 & 0.48991 \\
Exotic Species & 0.36415 & 0.04998 & 0.39699 & 0.17657 & 0.75233 \\
Weedy Species & 0.90853 & 0.05908 & -0.03434 & -0.03582 & 0.26481 \\
PAR 2015 & 0.15902 & 0.89806 & 0.13925 & 0.06246 & -0.12128 \\
\hline
\end{tabular}

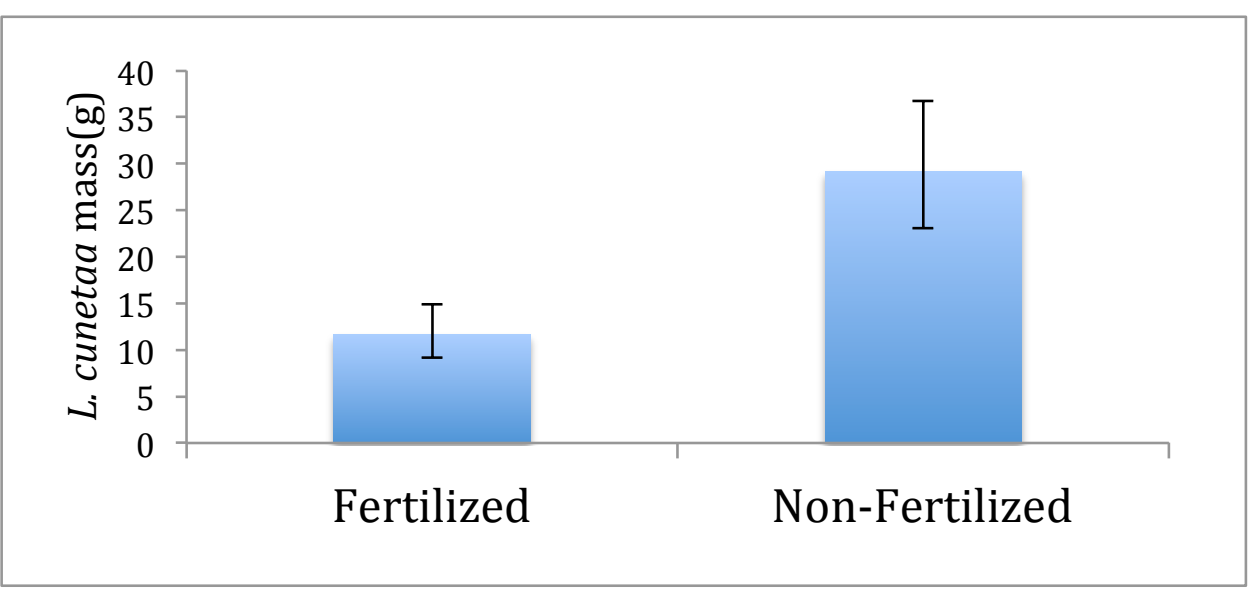

Fig. 1. Mean $( \pm$ se $)$ L. cuneata dry mass collected from fertilized and non-fertilized plots in 2015. 
MANOVA revealed highly significant differences in shoot mass and length among the legume species (Pillai's Trace, $F_{10,24}=27.59, P=<0.0001$, Fig. 2). The larger magnitude of the standard canonical coefficient $($ length $=-1.0584$, mass $=4.9453)$ indicated that mass explained more of the variation among species than did shoot length and the opposite signs indicate the mass and length tend to be negatively correlated. Two species, L. cuneata and Baptisia alba (White Wild Indigo), stand out from the other legumes. B. alba is high in mass, whereas $L$. cuneata has greatest allocation to length.

A flowering phenology (Fig. 3) produced with phenological data shows beginning and ending of flowering for all species found in experimental plots. L. cuneata is among the last of all species, and the last legume, to flower on the study site. In addition, L. cuneata flowers over a month later than its congener, $L$. capitata. The flowering of $L$. cuneata overlaps with few species and no legumes on our field site. 


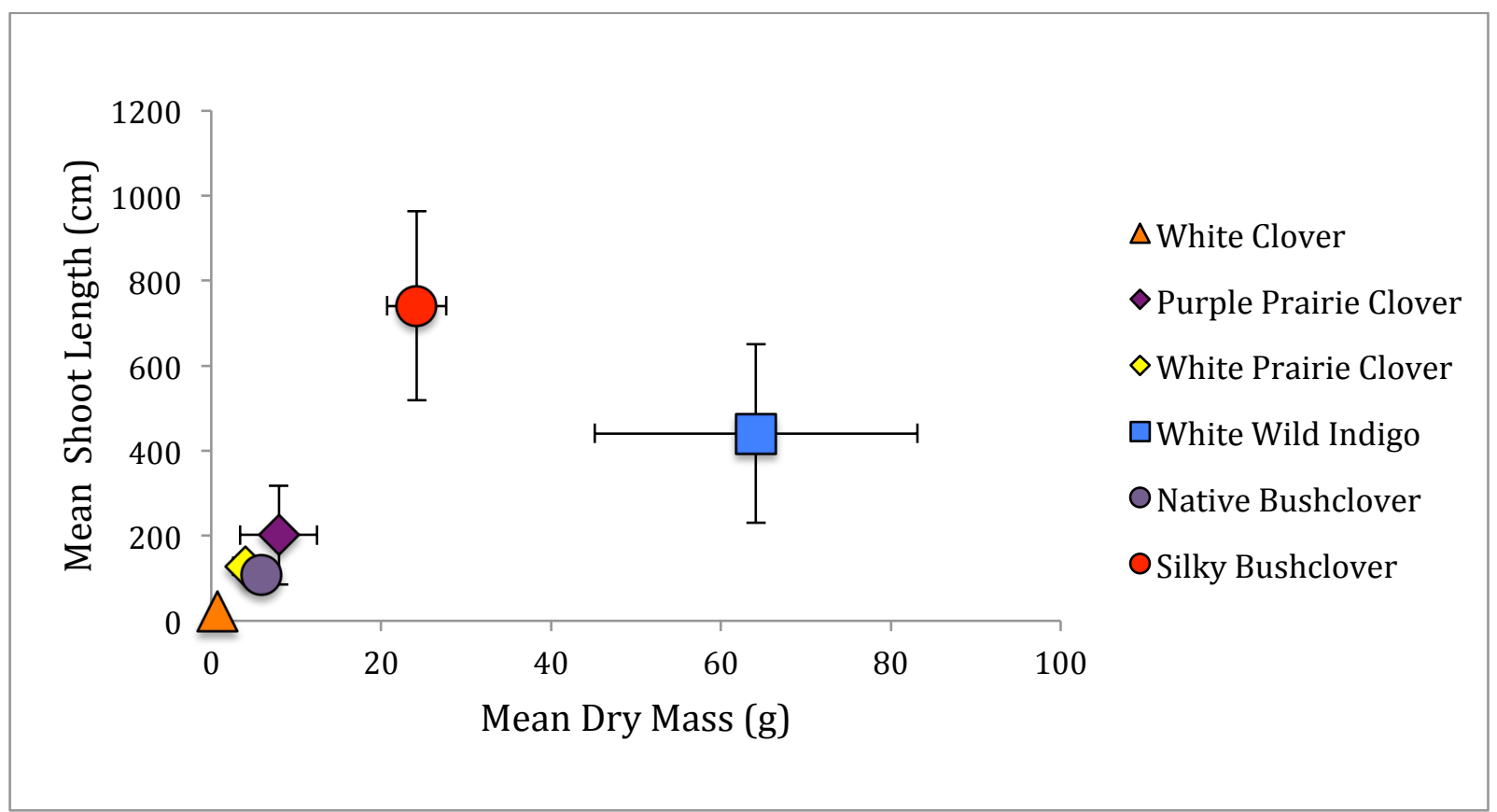

Fig. 2. Mean shoot length and mean dry mass of the six legume species present on the study site. Bars indicate standard errors. White clover and silky bushclover are non-native legume species found in experimental plots on John English Prairie. 


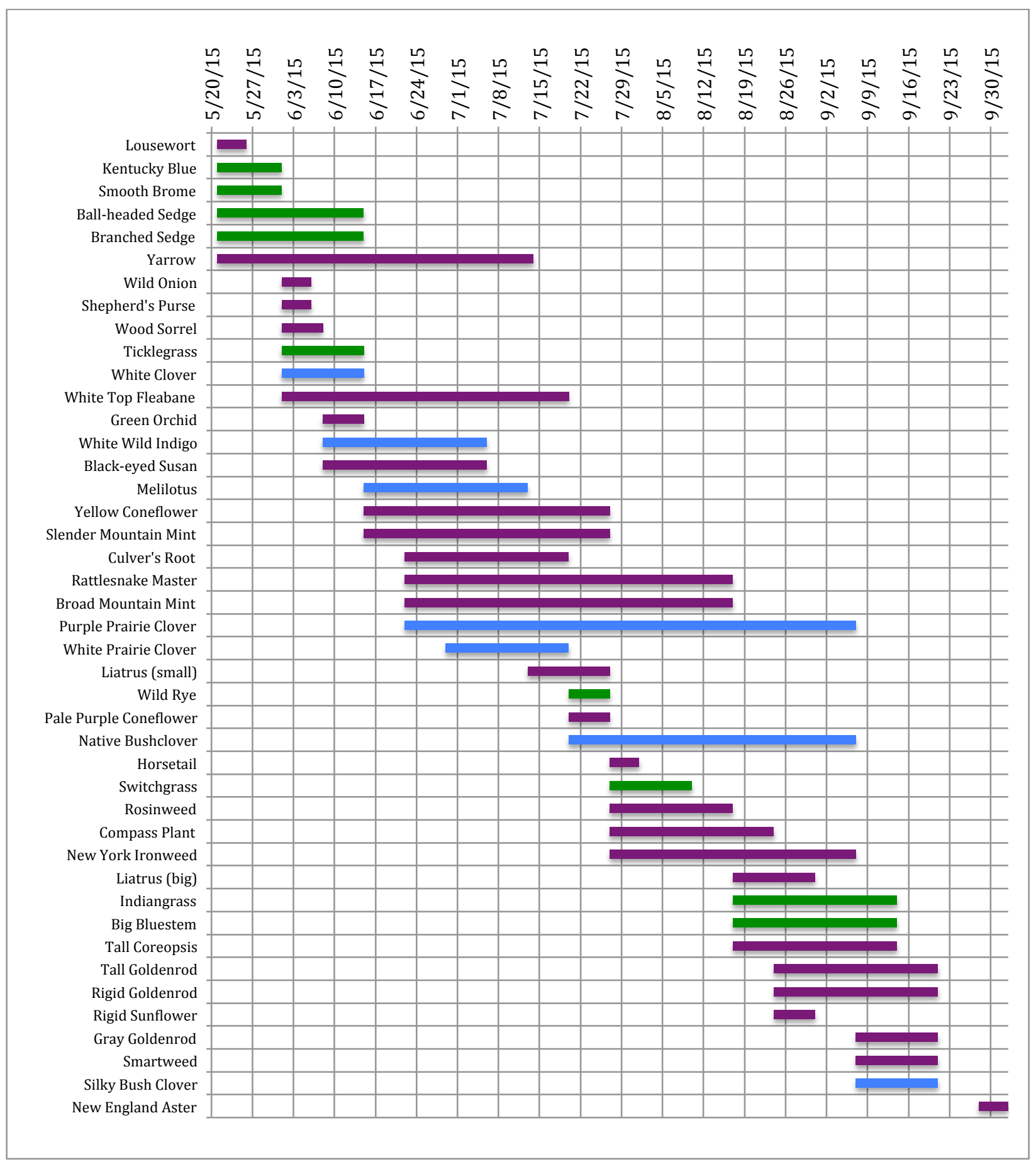

Fig. 3. Flowering times of species within experimental plots on John English Prairie study site.

(green $=$ graminoids, blue $=$ legumes, purple $=$ forbs $)$ 
By 2009, L. cuneata had invaded 29 of the 96 experimental plots, and all 96 plots were invaded by 2015. The logistic regression showed that species richness in the plots without L. cuneata in 2009 did not significantly affect entry by L. cuneata into these plots by 2015 (Wald $\left.\chi_{(1)}^{2}=1.8158, P=0.1778\right)$. Plots with a small number of species in this year were no more likely to have L. cuneata present by 2015 .

Likewise, species richness in 2009 did not significantly affect change in L. cuneata biomass between 2009 and $2015(P=0.3717)$. However, forbs $(P=0.0096)$ and legumes $(P=0.0245)$ were negatively correlated with the growth of $L$. cuneata. Plots that had a greater mass of these two functional groups in 2008 showed less growth of L. cuneata in 2015. By contrast, graminoids significantly and positively affected $L$. cuneata $(P=0.0130)$, meaning that the more grass present in a plot in 2008 , the more growth of L. cuneata by 2015 . The hemiparasite Pedicularis canadensis had no significant effect on $L$. cuneata growth $(P=0.1837)$. 


\section{CHAPTER IV: DISCUSSION}

This study focused on two hypotheses that were possible explanations for the invasion and spread of Lespedeza cuneata in a tallgrass prairie community. Darwin's naturalization hypothesis postulates that exotic species are less likely to establish in communities with related species because similarity in morphology and function promotes intense competition for

resources. The Darwin's naturalization hypothesis generally was supported by this study, as the mass of L. cuneata and the mass of other legumes were negatively associated. Furthermore, phenological differences between legumes on our study site and L. cuneata provide more evidence in support of this hypothesis.

The assumption that invaders are less successful in communities with more species, as stated by the biotic resistance hypothesis, generally was not supported. This hypothesis postulates that species-rich communities have more effective competitors, herbivores, and pathogens, and use resources efficiently, thus leaving no room for invaders. However, my results show that L. cuneata's invasion had no increased success when invading plots that had fewer potential competitors.

\section{Darwin's Naturalization Hypothesis}

Darwin's naturalization hypothesis predicts a negative correlation between L. cuneata and other legumes because the similarity in morphology and function of related species would promote competition for resources (Darwin 1859; MacArthur and Levins 1967; Hierro et al. 2005; Pearson et al. 2012). Consistent with prediction, my results show that the mass of $L$. cuneata decreased as the functionally similar legumes on the study site increased. In addition, observations showed that L. cuneata is significantly different from the other legume species 
located on our field site in both shoot length and mass. L. cuneata has a high allocation to shoot length, whereas others species such as $B$. alba have greater allocation to mass.

All legumes, including L. cuneata are nitrogen-fixing, so they play the same functional role within a community, as well as being phylogenetically related. How then, does $L$. cuneata invade a community that includes these other legume species? Differences between $L$. cuneata and native legumes in terms of phenology, seed production, morphology, and chemistry may help to answer this question. Lespedeza cuneata is among the last species and is the last legume to flower on the study site. L. cuneata flowers a little over a month later than its native congener, L. capitata. Since L. cuneata flowers later than other legumes, it avoids competition for pollinators with those species. However, if flowering time for these species did overlap, it is likely that $L$. cuneata would still be successful. Even though both Lespedeza species exhibit both flower types, $L$. cuneata has an advantage over its native congener, L. capitata. At peak flowering time, chasmogamous flower production by L. cuneata is $>20 \mathrm{X}$ that of native Lespedeza species (Woods et al. 2009). Due to the large number of flowers produced that attract pollinators, $L$. cuneata benefits from pollination more than its native Lespedeza congeners (Woods et al 2009). When the invasive L. cuneata was compared with three native Lespedeza species (L. capitata, L. violacea, and L. virginica), insect visitation rates were higher per plant on L. cuneata than on the native congener species (Woods et al. 2012). Lespedeza cuneata was a strong competitor for pollinators with L. capitata and L. violacea, which had fewer shared pollinators (Woods et al. 2012).

Greater production of flowers and attraction of pollinators can increase propagule pressure and population growth. A life table response experiment showed that when compared to $L$. virginica, $L$. cuneata produced more seeds with higher germination. The majority of $L$. 
virginica seeds stay in the seed bank, whereas the seeds of $L$. cuneata germinate very quickly, which allows for a quicker population growth of L. cuneata (Schutzenhofer et al. 2009). Thus, once it successfully establishes, L. cuneata has great potential to proliferate.

Lespedeza cuneata exhibits a growth form and chemistry distinct from other legumes on the site. L. cuneata allocates greater biomass to leaves, resulting in a higher total leaf area, compared to L. capitata (Smith and Knapp 2001). This is consistent with studies that have found exotic species have a higher specific leaf area, compared to native plants (Allred et al. 2010; Baruch and Goldstein 1999; Lake and Leishman 2004). Higher specific leaf area shades out species below and allows for greater light absorption. Lespedeza cuneata grows tall, coarse stems that form dense stands, a characteristic unlike other legumes growing on the field site. These dense stands limit the amount of light available to the species underneath, thus shading them out (Brandon et al. 2004; Reinhart et al. 2006). Lespedeza cuneata has tannin-containing allelopathic leaf litter, which no other co-occurring legumes produce (Langdale and Giddens 1967, Kalburtji and Mosjidis 1992). This tannin-containing leaf litter has the potential to suppress or inhibit its native competitors (Callaway and Ridenour 2004; Hierro et al. 2005). Thus, once established, L. cuneata's distinctive growth form and chemistry may provide a competitive edge over native species. Experiments showing the affects of this tannin-containing litter on co-occuring species is discussed in depth with the novel weapons hypothesis in following pages.

\section{Biotic Resistance Hypothesis}

Overall, the biotic resistance hypothesis, which predicted that $L$. cuneata would be negatively associated with the number of species present in the plot, was not supported. Using 
species richness as an index of community diversity, there was no trend of L. cuneata more successfully invading plots with fewer potential competitors. This is consistent with results of another study that suggests species identity is more important than species richness (Crawley et al. 1999). While species richness was found unimportant in terms of invasion, perhaps the sheer mass of individuals present does matter. L. cuneata was less successful in plots with greater mass of forbs and legumes, which suggests that dense plots are potentially more resistant to invasion. The mass of graminoids was positively associated with $L$. cuneata, most likely due to the intense competition that occurs with forbs and legumes. Where grass is low, forbs and legumes are more abundant, thus reducing the growth of L. cuneata.

Fertilizer reduced the growth of L. cuneata biomass, even though the treatment led to greater overall plot biomass (Borowicz and Armstrong 2012). Although nitrogen fixation gives Lespedeza cuneata an advantage over non-legume species in non-fertilized plots, when plots are fertilized, the co-occurring species are given the resources necessary to compete with $L$. cuneata.

\section{Possible Contending Hypotheses}

The method of multiple working hypotheses is based on the idea that several hypotheses can be correct in explaining a phenomenon (Elliott and Brook 2007). There are more hypotheses that can explain how $L$. cuneata spreads throughout a system than the two hypotheses that were analyzed in this study. Described below are some hypotheses that can also potentially explain the invasion of $L$. cuneata in a system.

The ideal weed hypothesis describes life history characteristics and traits of the invasive species that allow them to outcompete the native species, thus facilitating invasion (Rejmanek and Richardson 1996; Sutherland et al. 2004). Sutherland et al. (2004) identified plant life 
history characteristics for non-weedy species, native weeds, non-native weeds, and non-native invasive weeds. Invasive weedy species were less likely to be forbs, and more likely to be perennial, monoecious and self-incompatible than non-invasive species (Sutherland et al. 2004). Consistent with this description of invasive, non-native species, L. cuneata is a monoecious, perennial legume. However, L. cuneata produces both outcrossed chasmogamous and selfpollinated cleistogamous flowers, which does not agree with the findings of Sutherland et al. (2004). Nonetheless, this self-compatibility enables a single plant to proliferate in a new area, and could explain the success of $L$. cuneata at our study site.

Disturbance to a community can alter the structure and function, allowing invasive species the opportunity to colonize and establish in the disturbed area (Sher \& Hyatt 1999; Hood \& Naiman 2000; Colautti et al. 2006). The removal of Pedicularis canadensis in experimental plots could act as a disturbance event if the empty space caused by this removal allows $L$. cuneata the opportunity to establish, in addition to escaping the effects of the hemiparasite. However, we see that this is not the case, assuming that the removal treatment acted as an actual disturbance to the community. When the removal treatment of $P$. canadensis was included in our various statistical analyses, it was non-significant. This shows that in plots that were disturbed due to removal of $P$. canadensis, L. cuneata did not show increased establishment. From our results, we would reject this hypothesis as being a possible explanation for the spread of $L$. cuneata at our site.

The evolution of increased competitive ability (EICA) hypothesis posits that the lack of natural enemies allows the invasive species to allocate resources to functions that will allow it to be more competitive in its invaded range, instead of using those resources to combat enemies (Blossey \& Notzgold 1995; Callaway and Ridenour 2004; Joshi and Vrieling 2005). We would 
predict that in its introduced range, L. cuneata should exhibit reduced defenses against its native enemies, and invest more in traits that allow greater competition with native species. When comparing the ancestral genotype of L. cuneata introduced in 1930, with the modern-day North American invasive and with native Japanese genotypes, the North American invasive genotype outcompeted both the Japanese native and ancestral genotypes (Beaton et al. 2011). The invasive North American genotype exhibited greater aboveground biomass than the other genotypes, thus showing that it less affected by its competitors (Beaton et al. 2011). This study suggests that $L$. cuneata exhibits increased competitive abilities when introduced into a new range.

Novel weapons are allelopathic chemicals which invasive species can release that can increase invasion success against native species not adapted to these chemicals (Callaway and Ridenour 2004; Hierro et al 2005). Lespedeza cuneata has tannin-containing leaves that fall to the ground in the form of litter (Corbett 2010). Residues of L. cuneata stems reduced growth in corn, which then led to the further investigation of this novel weapon (Langdale and Giddens 1967). A study investigating the effects of $L$. cuneata residues on warm-season grasses showed that the residues had a negative effect on bermudagrass (Cynodon dactylon) and bahiagrass (Paspalum notatum) growth, but did not affect the germination or seedling emergence of either species (Kalburtji and Mosjidis 1992). Kalburtji and Mosjidis (1993) followed with another study to examine the effects of $L$. cuneata residues on cool-season grasses. Greenhouse experiments showed that germination, emergence of seedlings as well as seedling growth, nitrogen concentration and aboveground biomass of tall fescue (Festuca arundinacea) were reduced. In addition, aboveground biomass and nitrogen concentration in ryegrass (Lolium multiflorum) were reduced by L. cuneata residues. The addition of nitrogen fertilizer compensated for negative effects on both species. This suggests that the addition of nitrogen may 
be needed to enhance growth that would otherwise be curtailed by the residues from L. cuneata (Kalburtji and Mosjidis 1993). Dudley and Fick (2003) found that when exposed to stem and leaf residues, none of the grasses tested showed any reduction in growth. However, germination rates were reduced for several of the species tested including big bluestem (15-27\% reduction), Indian grass (25-39\% reduction) and Kentucky bluegrass (47-60\% reduction). This suggests that while growth of these grasses may not be affected, the success of germination is. Little bluestem was in no way affected by L. cuneata residues (Dudley and Fick 2003). The results of these studies show that there is a no agreement when it comes to reporting the effect of allelopathic chemicals in L. cuneata on other species. While this question has been tested on a limited number of grasses, the results vary widely. From only an effect on growth and no germination or emergence effects to no effect on growth and a reduction in germination, we see that more studies need to be carried out on this topic. There is a lack of consensus surrounding this hypothesis in relation to $L$. cuneata.

\section{Recommendations for Management}

Darwin's naturalization hypothesis suggests increasing the abundance of native species (Catford et al. 2009). Greater mass of legumes seems to afford some resistance to invasion, or at least limits the rate of invasion growth. For this reason, increasing plantings of native legumes in tallgrass prairie restoration and reconstruction efforts could keep invasive legumes at bay.

Annual burning of tallgrass prairies scarifies the seed of L. cuneata thus enhancing its germination (Cummings et al. 2007). If the management goal is to eradicate L. cuneata as

quickly as possible, annual burning in the spring will more rapidly deplete the massive seed bank that $L$. cuneata creates. If proper continued management is not carried out in the correct 
timeframe, denser stands of $L$. cuneata will form, thus adding to the invasion. Correct application of herbicide to kill the resprouted L. cuneata seedlings would keep increasing invasion at bay, as spring burning increases the establishment of $L$ cuneata. Alternatively, growing season prescribed fire carried out in the summer would reduce seed set for that year. Growing season prescribed fire will only be successful if the site is not previously spring burned, as thatch and litter are imperative for ignition. 


\section{CHAPTER V: RELEVANCE AND CONCLUSIONS}

Due to the significant damage that invasive species can cause, studies of their interactions within natural communities are vital in order to inform conservation efforts. In Illinois, exotic species are of particular threat to the tallgrass prairie, an ecosystem that has experienced significant decline in area throughout the state (Noss et al. 1995). Tallgrass prairies have become highly fragmented in Illinois, with $0.01 \%$ of the original prairie remaining (Samson and Knopf 1994). In prairie reconstructions that are carried out on degraded agricultural fields, exotic species can invade and dominate quickly (Goldblum et al. 2013).

Identifying mechanisms by which invasion occurs is essential for informing conservation management strategies. At the John English Prairie field site, the L. cuneata invasion is beyond the possibilities of eradication. For systems that have been so heavily invaded such as my field site, only control and management efforts are feasible. It is sad to see a reconstruction effort, such as the one carried out on John English Prairie, fall prey to such an aggressive, uncontrollable invasive species.

Further studies are needed to evaluate more hypotheses related to L. cuneata in order to complete the story of its mechanisms of successful invasion. This study has provided valuable information that will aid management efforts in the future. 


\section{REFERENCES}

Allred BW, Fuhlendorf SD, Monaco TA, Will RE (2010) Morphological and physiological traits in the success of the invasive plant Lespedeza cuneata. Biol. Invasions 12:739-749. doi:10.1007/s10520-009-9476-6

Alpert P (2006) The advantages and disadvantages of being introduced. Biol. Invasions 8:15231534. doi:10.1007/s10530-005-5844-z

Baruch Z, Pattison RR, Goldstein G (2000) Responses to light and water availability of four invasive Melastomataceae in the Hawaiian Islands. Int. J. Plant Sci. 161:107-118. doi: $10.1086 / 314233$

Beaton LL, Van Zandt PA, Esselman EJ, Knight TM (2011) Comparison of the herbivore defense and competitive ability of ancestral and modern genotypes of an invasive plant, Lespedeza cuneata. Oikos 120:1413-1419. doi:10.1111/j.1600-0706.2011.18893.x

Blossey B, Notzgold R (1995) Evolution of increased competitive ability in invasive nonindigenous plants: a hypothesis. J. Ecology 83:887-889. doi:10.2307/2261425

Brandon AL, Gibson, DJ, Middleton BA (2004) Mechanisms for dominance in an early successional old field by the invasive non-native Lespedeza cuneata (Dum. Cours.) G. Don. Biol. Invasions 6:483-493. doi:10.1023/B.BINV.0000041561.71407.f5

Borowicz VA, Armstrong JE (2012) Resource limitation and the role of a hemiparasite on a restored prairie. Oecologia 169.3:783-792. doi:10.1007/s00442-011-2222-7

Callaway RM, Ridenour WM (2004) Novel weapons: invasive success and the evolution of increased competitive ability. Frontiers in Ecology and the Environment 2:436-443. doi:10.1890/1540-9295(2004)[0436:NWISAT]2.0.C);2 
Cane JH, Snyder G (1986) Searching for pollinators of sericea lespedeza. Highlights of Agricultural Research. Auburn University, Alabama Agricultural Experiment Station $33: 13$.

Catford JA, Vesk PA, Richardson DM, Pysek P (2012) Quantifying levels of biological invasion: towards the objective classification of invaded and invasible ecosystems. Global Change Biology 18:44-62. doi:10.1111/j.1365-2486.2011.02549.x

Catford JA, Jansson R, Nilsson C (2009) Reducing redundancy in invasion ecology by integrating hypotheses into a single theoretical framework. Diversity and distributions $15.1: 22-40$

Chapin FS III, Zavaleta ES, Eviner VT, Naylor RL, Vitousek PM, Reynolds HL, Hooper DU, Lavorel S, Sala OE, Hobbie SE, Mack MC, Diaz S (2000) Consequences of changing biodiversity. Nature 405:234-242. doi:10.1038/35012241

Colautti RI, Grigorovich IA, MacIssac HJ (2006) Propagule pressure: a null model for biological invasions. Biol. Invasions 8:1023-1037. doi:10.1007/s10530-005-3735-y

Corbett, EC (2010) Allelopathic Effects of Sericea Lespedeza on Prairie Species. Proceedings of the North American Prairie Conference 21:108-115

Coykendall KE, Houseman GR (2014) Lespedeza cuneata invasion alters soils facilitating its own growth. Biol. Invasions 16:1735-1742. doi:10.1007/s10530-013-0623-8

Crawley MJ, Brown SL, Heard MS, Edwards GR (1999) Invasion-resistance in experimental grassland communities: species richness or species identity? Ecology Letters 2:140-148. 
Cummings DC, Bidwell TG, Medlin CR, Fuhlendorf SD, Elmore RD, Weir JR (2007) Fact Sheet: Ecology and management of sericea lespedeza [Online]. Oklahoma Cooperative Extension Service NREM-2874. Stillwater, OK: Oklahoma State University, Natural Resource Ecology and Management 7 p.

Daehler CC (2003) Performance comparisons of co-occurring native and alien plants: Implications for conservation and restoration. A Review of Ecology, Evolution and Systematics 34:183-211.

Darwin C (1859) On the origin of species by means of natural selection, or the preservation of favoured races in the struggle for life.

Daubenmire, Rexford (1959) A canopy coverage method of vegetation analysis. Northwest Science 33:43-64.

Davis MA, Grime JP, Thompson K (2000) Fluctuating resources in plant communities: a general theory of invasability. J. Ecology 88:528-534. doi:10.1046/j.1365-2745.2000.00473.x

Dudley DM, Fick WH (2003) Effects of sericea lespedeza residues on selected tallgrass prairie grasses. Transactions of the Kansas Academy of Science 106:166-170. doi:10.1660/00228443(2003)106[0166:EOSLRO]2.0.C);2

Eddy TA, Moore CM (1998) Effects of sericea lespedeza (Lespedeza cuneata [Dum.] G. Don) invasion in oak savannas in Kansas. Transaction of the Wisconsin Academy of Sciences, Arts and Letters 86:57-62

Elliott LP, Brook BW (2007) Revisiting Chamberlin: Multiple Working Hypotheses for the $21^{\text {st }}$ Century. BioScience 57:608-614. doi: 10.1641/b570708 
Foster BL, Houseman GR, Hall DR, Hinman, SE (2015) Does tallgrass prairie restoration enhance the invasion resistance of post-agricultural lands? Biol. Invasions 17:3579-3590. doi: $10.1007 / \mathrm{s} 10530-015-0979-\mathrm{z}$

Goldblum D, Glaves BP, Rigg LS, Kleiman B (2013) The impact of Seed Mix Weight on Diversity and Species Composition in a Tallgrass Prairie Restoration Planting, Nachusa Grasslands, Illinois, USA. Ecological Restoration 31:154-167. doi:10.3368/er.31.2.154

Hierro JL, Maron JL, Callaway RM (2005) A biogeographical approach to plant invasions: the importance of studying exotics in their introduced and native range. J. Ecology 93:5-15. doi:10.1111/j.0022-0477.2004.00953.x

Hood WG, Naiman RJ (2000) Vulnerability of riparian zones to invasion by exotic vascular plants. Plant Ecology 148:105-114. doi:10.1023/A:1009800327334

Hoveland CS, Buchanan GA, Donnelly ED (1971) Establishment of sericea lespedeza. Weed Science 19:21-24.

Hoveland CS, Donnelly ED (1985) The lespedezas. In M. E. Health, R.F Barnes, and D. S. Metcalfe, eds. Forages: The science of grassland agriculture. Iowa State Press, Ames, Iowa.

Joshi J, Vrieling K (2005) The enemy release and EICA hypothesis revisited: incorporating the fundamental difference between specialist and generalist herbivores. Ecology Letters 8:704-714. doi:10.1111/j.1461-0248.2005-00769.x

Kawano S (1981) Trade-off relationships between some reproductive characteristics in plants with special reference to life history strategy. S. Bot. Mag. Tokyo 94:285-294. doi:10.1007/BF02488617 
Kalburtji KL, Mosjidis JA (1992) Effects of Sericea Lespedeza Residues on Warm-Season Grasses. J. Range Management 45:441-444. doi:10.2307/4002899

Kalburtji KL, Mosjidis JA (1993) Effects of Sericea Lespedeza Residues on Cool-Season Grasses. J. Range Management 46:315-319.

Lake JC, Leishman MR (2004) Invasion success of exotics in natural ecosystems: the role of disturbance, plant attributes and freedom from herbivores. Biol. Conserv. 117:215-226. doi:10.1016/S0006-3207(03)00294-5

Langdale GW, Giddens JE (1967) Phytotoxic phenolic compounds in sericea lespedeza resides. Argron. J. 59:581-584. doi:10.2134/agronj1967.00021962005900060028x

Levine JM, Adler PB, Yelenik SG (2004) A meta-analysis of biotic resistance to exotic plant invasions. Ecology Letters 7:975-989. doi:10.1111/j.1461-0248.2004.00657.x

MacArthur R, Levins R (1967) The limiting similarity, convergence, and divergence of coexisting species. The american naturalist 101:377-385.

McLeod ML, Cleveland CC, Lekberg Y, Maron JL, Philippot L, Bru D, Callaway RM (2016) Exotic invasive plants increase productivity, abundance of ammonia-oxidizing bacteria, and nitrogen availability in intermountain grasslands. J. Ecol. 104:994-1002. doi:10.1111/1365-2745.12584

Noss RF, LaRoae ET, Scott JM (1995) Endangered ecosystems of the United States: a preliminary assessment of loss and degradation. US Department of the Interior, National Biological Service, Washington, DC, USA. v.28.

Ohiwi J (1965) Flora of Japan (In English). Smithsonian Institution pg.1076 
Ohlenbusch PD, Bidwell TD, Fick WH, Kilgore G, Scott W, Davidson J, Clubine S, Mayo J, Coffin M (2007) Sericea lespedeza: history, characteristics, and identification. Kansas State University Agricultural Experiment Station 6 p.

Parker JD, Hay ME (2005) Biotic resistance to plant invasions? Native herbivores prefer nonnative plants. Ecology Letters 8:959-967

Pearson DE, Ortega YK, Sears SJ (2012) Darwin's naturalization hypothesis up-close: Intermountain grassland invaders differ morphologically and phenologically from native community dominants. Biol. Invasions 12:901-913. doi:10.1007/s10530-011-0126-4

Pimentel D, Zuniga R, Morrison D (2005) Update on the environmental and economic costs associated with alien-invasive species in the United States. Ecological Economics 52:273-288. doi:10.1016/j.ecolecon.2004.10.002

Rejmanek M, Richardson DM (1996) What attributes make some plant species more invasive? Ecology 77:1655-1661. doi:10.2307/2265768

Reinhart KO, Gurnee J, Tirado R, Callaway RM (2006) Invasion through quantitative effects: intense shade drives native decline and invasive success. Ecological Applications 16:1821-1831. doi:10.1890/1051-0761(2006)016[1821:ITQEIS]2.0.CO;2

Samson F, Knopf F (1994) Prairie conservation in North America. BioScience 44:418-421.

Schutzenhofer MR, Valone TJ, Knight, TM (2009) Herbivory and population dynamics of invasive and native Lespedeza. Oecologia 161:57-66. doi:10.1007/s00442-009-1354-5

Sher AA, Hyatt LA (1999) The disturbed resource-flux invasion matrix: a new framework for patterns of plant invasion. Biol. Invasions 1:107-114. doi:10.1023/A:1010050420466 
Smith MD, Knapp AK (2001) Physiological and Morphological Traits of Exotic, Invasive Exotic, and Native Plant Species in Tallgrass Prairie. Int. J. Plant Sci. 162:785-792. doi: $10.1086 / 320774$

Sutherland S (2004) What makes a weed a weed: Life History Traits of Native and Exotic Plants in the USA. Oecologia 141:24-39. doi:10.1007/s00442-004-1628.x

United States Department of Agriculture. Natural Resources Conservation Service: PLANTS Database. https://plants.usda.gov/core/profile?symbol=LECU

White EM, Wilson JC, Clarke AR (2006) Biotic indirect effects: a neglected concept in invasion biology. Diversity and Distributions 12:443-455.

Williamson M, Fitter A (1996) The varying success of invaders. Ecology 77:1661-1666.

Woods TM (2006) A comparison of the reproductive systems of the invasive Lespedeza cuneata (Dum.-Cours.) G. Don (Fabaceae) with three native congeners in the Flint Hills region of the tallgrass prairie. M. S. Thesis, Kansas State University.

Woods TM, Hartnett DC, Ferguson CJ (2009) High propagule production and reproductive fitness homeostasis contribute to the invasiveness of Lespedeza cuneata (Fabaceae). Biol. Invasions 11:1913-1927. doi:10.1007/s10530-008-9369-0

Woods TM, Jonas JL, Ferguson CJ (2012) The invasive Lespedeza cuneata attracts more insect pollinators than native congeners in tallgrass prairie with variable impacts. Biol. Invasions 14:1045-1059. doi:10.1007/s10530-011-0138-0

Yannarell AC, Busby RR, Denight ML, Gebhart DL, Taylor SJ (2011) Soil bacteria and fungi respond on different spatial scales to invasion by the legume Lespedeza cuneata. Front. Microbiol. 2:127. doi: 10.3389/fmicb.2011.00127 